\title{
Persistence of aversions to larkspur in naive and native cattle
}

\author{
MICHAEL H. RALPHS
}

Author is rangeland scientist, USDA/ARS Poisonous Plant Lab,. 1150 E. 1400 N., Logan, Ut. 84341.

\begin{abstract}
The objective of this study was to create and maintain a long lasting aversion to tall larkspur (Delphinium barbeyi Huth) under field grazing conditions. Two grazing trials were conducted: the first used cattle naive to larkspur, and the second used cattle that were familiar with larkspur. In the first trial, 12 mature cows that were not familiar with larkspur were randomly allocated to Averted and Control groups $(n=6)$. They were fed larkspur (a novel food) and the Averted group was dosed with lithium chloride ( $200 \mathrm{mg} / \mathrm{kg}$ body weight) to create the aversion. Both groups were then taken to larkspur-infested mountain rangeland where they grazed in 2 separate pastures during the late summer of 1993, 1994, and 1995. The aversion was not reinforced in 1994 or 1995. Diets were quantified by bite count. The Averted group abstained from eating larkspur for 3 years. The Control group grazed larkspur for an average of $14 \%$ of bites. Three Control cows died from larkspur poisoning in 1993, and another cow was poisoned, but survived in 1994. During the last 2 weeks of the 1995 trial, the Averted and Control groups were placed together, and the social influence of the Control cows eating larkspur caused the Averted cows to sample larkspur and gradually extinguished the aversion. In the second trial (1994 and 1995), 5 native cows that had grazed on the allotment and were familiar with larkspur were averted to larkspur by the procedure described above. They abstained from eating larkspur while grazing separately, but extinguished the aversion when placed with nonaverted Control cows at the end of the study in 1995. Aversions are retained in long term memory and may last indefinitely if averted cattle graze separately.
\end{abstract}

Key Words: conditioned food aversion, social facilitation, cattle grazing, poisonous plant, tall larkspur, Delphinium barbeyi

The study of conditioned food aversions is a prominent field of research in the behavioral sciences (Braveman and Bronstein 1985). Zahorik and Houpt $(1977,1990)$ first demonstrated that livestock could be averted to specific foods. Laycock (1978) introduced this concept to the Range Management profession, and suggested it may have potential to prevent livestock from eating poisonous plants. Provenza and Balph (1988) proposed that diet training (which encompass aversion conditioning) may

\footnotetext{
The author wishes to thank Bob and Anne McKune for the use of their corrals, cattle, and their encouragement; Connie Clementson and the U.S. Forest Service for use of the grazing allotment; Justin Williams, Jeff Hale, Rob Pate, and Lee Woolsey for data collection.

Manuscript accepted 2 Jul. 1996.
}

enable managers to shape grazing behavior of animals to meet management goals. Our goal has been to condition animals to avoid eating poisonous plants and thus avoid poisoning.

A series of experiments were conducted to aversely condition cattle to avoid eating tall larkspur (Delphinium barbeyi L. Huth), an important poisonous plant on mountain rangelands. Lane et al. (1990) fed heifers fresh larkspur in a pen, then dosed them with lithium chloride $(\mathrm{LiCl})$. They associated the induced illness with the taste of larkspur and avoided eating larkspur when released in larkspur-infested pastures. This aversion lasted into the next year's grazing season. However, when the averted heifers were placed with non-averted cohorts that were readily grazing larkspur, they started sampling larkspur and the aversion extinguished. Averted cattle must be grazed separately to maintain the aversion (Ralphs and Olsen 1990). We also found that mature cows retained aversions better than younger animals (Ralphs and Cheney 1993), and that novelty of taste is important in forming strong aversions (Ralphs et al. 1996, Burritt and Provenza 1996)

The objective of the first study was to implement the knowledge gained from previous research to create and maintain a long lasting aversion in cattle that were naive to tall larkspur. A second study was conducted to determine if native cows with previous exposure to larkspur could be averted. Aversions to familiar foods are more difficult to create because these foods are considered safe (Nachman et al. 1977).

\section{Methods}

The grazing studies were conducted $16 \mathrm{~km}$ west of Yampa, Colo. on the Routt National Forest. The habitat type was aspen (Populus tremuloides Michx.)/tall forb. Tall larkspur was the dominant forb, with cow parsnip (Heracleum lanatum Michx.), sweetcicely (Osmorhiza acidentalis [Nutt] Torr.), meadowrue (Thalictrum fendleri Engelm. ex Gray) and American vetch (Vica americana Muhl. ex Wild.) comprising the majority of palatable forbs. Mountain brome (Bromus carinatus Hooker \& Arn.) was the dominant grass, and Kentucky bluegrass (Poa pratensis L.) occurred in the understory. Standing crop of tall larkspur, other forbs, and grasses was estimated at the beginning of each trial by clipping ten, $1 \times 0.25 \mathrm{~m}$ quadrats systematically located at 20 step intervals along paced transects through the middle of each pasture. Samples were dried in a forced air oven at $60^{\circ} \mathrm{C}$ for 48 hours then weighed. Total standing crop averaged $2,856 \mathrm{~kg} / \mathrm{ha}$ over the 3 years. Tall larkspur comprised $41 \%$ of the standing crop, other forbs comprised $46 \%$, and grasses $13 \%$. 


\section{Naive Cows 1993 to 1995}

Twelve cows (Hereford and Angus) were purchased from ranches in southeastern Idaho. The cows were mature (3-4 yr old, $435 \mathrm{~kg} \pm 15 \mathrm{SE}$ ) and had not been on mountain rangeland nor were they familiar with larkspur. The cows were allotted randomly to Averted and Control treatment groups.

The cows were transported to a ranch in Yampa, Colo. near the study site and allowed 2 days to acclimate to the new surroundings. The evening before aversion conditioning, regular feed was withheld, and the cows were offered $9 \mathrm{~kg}$ fresh larkspur. Some of the cows were reluctant to eat it on the first exposure. They were offered $15 \mathrm{~kg}$ of larkspur the next morning and all of them readily ate it. Cows in the Averted group were restrained in a chute and gavaged with lithium chloride ( $\mathrm{LiCl} 200 \mathrm{mg} / \mathrm{kg}$ body weight) via stomach tube. Their regular ration of hay was withheld until evening so there was no interference between the induced illness and the taste of the novel larkspur. The Averted cows were allowed to recover for 3 days and fed alfalfa hay morning and evening. The Control group was fed $5 \mathrm{~kg}$ of larkspur morning and evening before their regular ration of hay.

The aversion was tested and reinforced in paired and group feeding tests. Averted and Control cows were randomly paired together and each pair was offered fresh larkspur for $10 \mathrm{~min}$. each morning and evening for 3 days. The groups were then placed together in a group feeding situation and offered $9 \mathrm{~kg}$ of fresh larkspur. The social facilitation of the Control cows eating larkspur induced 2 of the Averted cows to sample larkspur, and they were dosed a second time with a lower dose of $\mathrm{LiCl}(100 \mathrm{mg} / \mathrm{kg} \mathrm{BW})$.

The 2 groups were transported to the grazing site and each group was randomly assigned to 1 of 2 adjacent larkspur-infested pastures. Diets were estimated by bite counts. Each cow was observed for $5 \mathrm{~min}$. periods and the number of bites of forage classes were counted (tall larkspur, other forbs, grass, shrubs). Cows were observed during the morning and evening grazing periods for an average of 3 to 5 observations on each cow each day.

The cows were retained for 3 years and the grazing trial was repeated in 1994 and 1995 at the same site to determine the longevity of the aversions. The aversions were not reinforced in 1994 or 1995. In 1993, the study ran from 2 to 25 August and the pasture sizes were $1.7 \mathrm{ha}$. The pasture size was increased to 3.3 ha in 1994 to accommodate the longer trials (21 July to 22 August). In 1995, the persistence trial ran from 2 to 15 August, and the social facilitation trial ran from 16 to 31 August. Individual cows were the experimental units to which the aversion treatment was applied. Hence, pastures were merely the area where the aversion was expressed. However, groups were rotated to the other pasture halfway through each trial to reduce any pasture difference in diet selection.

Percentage of bites of each forage class in diets during the 3 years the cattle grazed separately were transformed by arcsin and analyzed by a general linear model (SAS 1988) using a split-plot design. Difference between groups was tested by the animal (within group) factor, and the year and group $X$ year interaction was tested by the year $X$ animal (within group) factor. There was a group $X$ year interaction for forbs and grasses in the diets, so the model was reduced and data were analyzed for each year separately comparing groups over days in a split-plot model. The difference between groups was tested by the animal (within group) factor, and day and the group $X$ day interaction was tested by the residual error. The percentage of bites of each forage class was averaged over observation periods each day for each cow before the analysis. Non-transformed means are presented in the tables and figures.

\section{Social Facilitation Trial, 1995}

The Averted and Control group were placed together at the end of the 1995 trial to determine if the aversion would remain under the pressure of social facilitation. The gates were opened and the cows were allowed to graze freely between the 2 pastures from August 15 to 31 . Bite counts were recorded as described previously. Diet data during the part of the trial when groups grazed together were transformed by arcsin and analyzed in a split plot design comparing groups over days of the trial.

\section{Native Cows, 1994 and 1995}

The objective of this trial was to determine if native cows that were familiar with larkspur, could be averted and abstain from eating it. Five native cows were obtained from a local rancher. They had grazed on the allotment for 2 to 5 years and had been exposed to larkspur. They were averted to larkspur as described in the first trial. Regular feed was withheld overnight, and they were offered fresh-picked larkspur the evening before and morning of conditioning. The Native cows readily ate larkspur and were gavaged with $\mathrm{LiCl}(200 \mathrm{mg} / \mathrm{kg} \mathrm{BW})$. They were allowed 3 days to recover, and offered larkspur morning and evening for 2 more days, but they refused. They were transported to the grazing area on the mountain and allowed to graze a larkspur-infested pasture (1.6 ha) from August 20 to September 6, 1994. The Control cows from the previous study were placed in an adjacent pasture for a comparison of larkspur intake. Bite counts were taken as described previously.

Three of the Native cows were available in 1995 (one had a calf), and were returned to the grazing site. They grazed a 2 ha pasture from August 16 to 23 . The control cows were placed with the native cows from August 23 to 31 to assess the influence of social facilitation on the larkspur aversion. Diet data were transformed by arcsin and analyzed separately for each year while the cattle grazed separately (persistence trial), and when they grazed together in 1995 (social facilitation trial), using the split-plot model described above.

\section{Results and Discussion}

\section{Naive Cows 1993-1995}

Following conditioning with $\mathrm{LiCl}$ in 1993 , the Averted cows abstained from grazing larkspur for 3 years while they grazed separately (Table 1). The optimal conditions for maintaining aversions (mature animals, averted to novel food, using a high dose of $\mathrm{LiCl}$ to induce intense gastrointestinal illness, and groups grazed separately to avoid social facilitation) combined to promote a long-lasting aversion to tall larkspur.

The Control cows consumed larkspur from 11 to $20 \%$ of their bites (Table 1). In 1993, 3 of the control cows died from larkspur poisoning. Symptoms of poisoning (muscular tremors and collapse) were observed in 2 other cows, but they survived. In 1994, one cow showed symptoms of poisoning; she collapsed and was not able to stand for 10-15 minutes, but she recovered. Even though these cattle were severely poisoned, they continued to eat larkspur after they recovered. Natural aversions to larkspur did not occur. Zahorik and Houpt (1977) suggested that free-ranging animals may have difficulty associating illness with a particular plant consumed during the course of a day. 
Table 1. Percentage of bites ( \pm standard error) of forage classes in Averted and non-averted Control cows.

\begin{tabular}{|c|c|c|c|c|c|}
\hline Year & Group & Larkspur & Forb & $\overline{\text { Grass }}$ & Shrub \\
\hline \multirow[t]{2}{*}{1993} & Averted & 0 & $\begin{array}{c}-(\%) \cdots \\
34 \pm 0.7 \\
*\end{array}$ & $64 \pm 0.8$ & $2 \pm 0.3$ \\
\hline & Control & $20 \pm 0.7$ & $28 \pm 0.7$ & $45 \pm 1$ & $6 \pm 0.6$ \\
\hline \multirow[t]{2}{*}{1994} & Averted & $\begin{array}{l}0 \\
*\end{array}$ & $\begin{array}{c}34 \pm 0.6 \\
*\end{array}$ & $63 \pm 0.5$ & $3 \pm 0.2$ \\
\hline & Control & $12 \pm 0.4$ & $23 \pm 0.4$ & $63 \pm 0.4$ & $3 \pm 0.2$ \\
\hline \multirow[t]{2}{*}{$\begin{array}{l}1995 \\
\text { Separate }\end{array}$} & Averted & $\begin{array}{l}0 \\
*\end{array}$ & $\underset{*}{67} \pm 2$ & $33 \pm 2$ & 0 \\
\hline & Control & $11 \pm 1$ & $58 \pm 1$ & $31 \pm 1$ & 0 \\
\hline \multirow[t]{2}{*}{$\begin{array}{l}1995 \\
\text { Together }\end{array}$} & Averted & $\begin{array}{l}6 \pm 1 \\
*\end{array}$ & $\begin{array}{c}73 \pm 2 \\
*\end{array}$ & $19 \pm 1$ & $2 \pm 0.4$ \\
\hline & Control & $10 \pm 1$ & $66 \pm 2$ & $23 \pm 2$ & $2 \pm 0.4$ \\
\hline
\end{tabular}

*Means in the same column within year and trial are different $(P<0.05)$.

Although grasses comprised only a small part of the standing crop, they dominated cattle diets in 1993 and 1994 (Table 2), but forbs dominated diets in both trials in 1995. Cow parsnip, sweetcicely, and vetch were preferred forbs. Small amounts of snowberry (Symphoricarpos oreophilus Gray) were consumed toward the end of the trials each year.

Table 2. Percentage of bites ( \pm standard error) of forage classes in Native cows that were averted to larkspur and non-averted Control cows.

\begin{tabular}{llcccc}
\hline Year & Group & Larkspur & Forb & Grass & Shrub \\
\hline \multirow{2}{*}{1994} & Native & $1 \pm 0.2$ & $29 \pm 0.6$ & $62 \pm 0.7$ & $8 \pm 0.5$ \\
& & $*$ & & & $*$ \\
& Control & $5 \pm 0.3$ & $28 \pm 0.6$ & $62 \pm 0.6$ & $5 \pm 0.3$ \\
1995 & Native & 0 & $80 \pm 3$ & $18 \pm 3$ & $1 \pm 0.6$ \\
Separate & & $*$ & & & \\
& Control & $10 \pm 0.8$ & $61 \pm 1$ & $29 \pm 1$ & $1 \pm 0.1$ \\
1995 & Native & $6 \pm 2$ & $74 \pm 3$ & $16 \pm 3$ & $5 \pm 1$ \\
Together & & $*$ & $*$ & $*$ & \\
& Control & $13 \pm 2$ & $61 \pm 2$ & $23 \pm 2$ & $2 \pm 1$ \\
\hline
\end{tabular}

* Means in the same column within year and trail are different $(\mathrm{P}<0.05)$.

\section{Native Cows 1994-1995}

The averted Native cows generally abstained from eating larkspur while grazing separately in both 1994 and 1995 (Table 2). One cow started eating larkspur in 1994 and consumed it for $4 \%$ of bites, but the other 4 cows abstained. The native cow that ate larkspur in 1994 was not available for the 1995 study.

These cows grazed on this allotment for 2 to 5 years, and had been exposed to larkspur, although it is not known whether they consumed it. The herd from which these cows were taken had experienced large losses to larkspur over the years. Even though it is difficult to form aversions to familiar foods (Nachman et al 1977, Burritt and Provenza 1996), these native cows formed aversions to larkspur. Ralphs et al. (1997) also averted steers that were familiar with white locoweed (Oxytropis sericea Nutt, $\mathrm{T} \& \mathrm{G}$ ) by dosing them with $\mathrm{LiCl}$ following their consumption of locoweed in the pasture.

\section{Social Facilitation Trials from Both Studies}

In the first study, Averted and Control groups were placed together on 16 August, and the Averted group gradually extinguished the aversion (Fig. 1). The mean larkspur consumption for the Averted group was lower than the Controls $(P=0.007$, Table $1)$, but there was a group $X$ day interaction $(P=0.02)$, indicating the Averted group increased larkspur consumption during the trial. They were consuming as much larkspur as the non-averted Control group at the end of the trial (Fig. 1). The Averted group did not consume larkspur for 7 days after the groups were placed together. In other larkspur aversion grazing trials, the averted groups started to eat larkspur within 3-4 days after being placed together (Lane et al. 1990, Ralphs and Olsen 1990, 1992). The optimal conditions described above apparently created a stronger aversion that lasted a few days longer than in previous trials, but the aversion extinguished in the end.

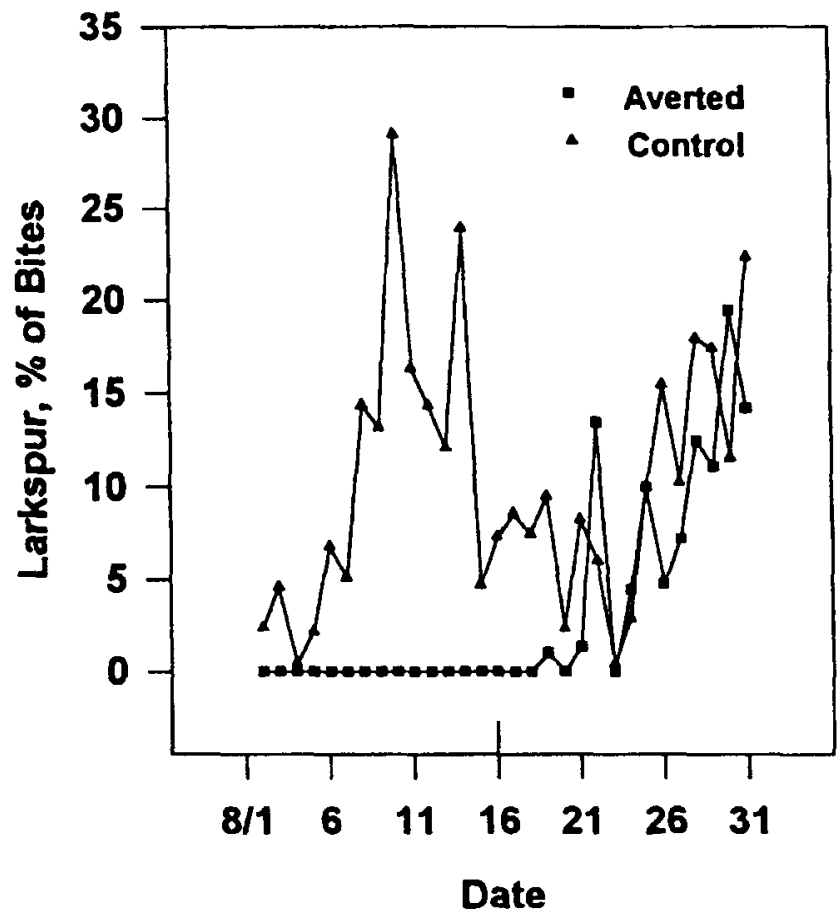

Fig. 1. Larkspur consumption ( $\%$ of bites) from Averted and nonaverted Control groups during the 1995 grazing trial. Cattle grazed in separate pastures from August 1 to 15, and were placed together in the same pasture in the social facilitation trial 16 to 31 August.

In the second study, the Native cows extinguished the aversion when placed in with the non-averted Controls in 1995 (Table 2). They started eating larkspur after 2 days, however mean consumption was less than half that of the controls $(P=0.01$, Table 2 ). There was no group $X$ day interaction in this part of the study $(P=0.57)$.

Our prior experiments have not been successful in reinforcing aversions to larkspur to withstand social facilitation. In our initial experiment (Lane et al. 1990), the averted heifers extinguished the aversion to larkspur when placed with non-averted cohorts that were readily grazing larkspur. We conducted several experiments to try to overcome the influence of social facilitation: rein- 
forcement of the aversion (Ralphs and Olsen 1990); use of native cattle that were familiar with the plant community (Ralphs unpublished data); and the use of larkspur alkaloid extract as the emetic to create an internal feedback when cattle start to sample larkspur (Ralphs and Olsen 1992). None of these practices were completely successful in overcoming social facilitation and maintaining total abstinence to larkspur when averted animals grazed with non-averted cohorts in the field. Social facilitation also caused cattle to extinguish aversions to alfalfa pellets (Olsen and Ralphs 1996); and ewes and lambs to extinguish aversions to mountain mahogany (Burritt and Provenza 1989) and calf manna (Thorhallsdottir et al. 1990). Raccoons, effectively averted against killing chickens, extinguished the aversion when they observed their kits killing and eating the chickens (Gustavson and Gustavson 1985). Finally, rats extinguished aversions to flavored liquids when exposed to cohorts that were consuming, or had recently consumed the liquid (Galef 1986). In rats, livestock, and humans, social influence is an important determinant of diet selection (Rozin and Zellner 1985). We conclude that aversions are not likely to be maintained in mixed group feeding or grazing situations.

\section{Conclusions}

Conditioned food aversion is a powerful experimental tool to modify animal diets (Galef 1985). We have shown that it is a potential management tool to prevent livestock from grazing poisonous plants. In the first experiment, naive cows retained aversions to larkspur for 3 years while grazing separately. In the second experiment, native cows retained aversions to larkspur for 2 years. Lane et al. (1990) also reported that heifers retained aversions to larkspur during his 2 year study. It appears that aversions, and subsequent hedonic shifts which make larkspur unpalatable, are retained in long-term memory (Garcia et al. 1985).

Aversion conditioning is an intensive management tool. It requires confining animals, forcing them to consume the target plant, dosing with an emetic, then testing the aversion. Large scale field and demonstration trials are needed to determine its practicality. However ranches which persistently lose animals to poisonous plants can afford to invest in practices that prevent losses.

Theoretically, novelty of taste is important in creating a strong and lasting aversion (Nachmann et al. 1977). However, native cattle that were familiar with larkspur, formed strong aversions to it. If native cattle can be successfully averted to larkspur, ranchers would not need to purchase naive replacement heifers that had not been exposed to larkspur.

Social facilitation is the most important factor preventing wide spread application of aversion conditioning. Averted animals, seeing others eating the target food, will sample it. If there is no adverse reaction, they will continue sampling and eventually extinguish the aversion. However, if averted animals can be grazed separately, aversion conditioning may provide an effective management tool to prevent animals from eating selected plants.

\section{Literature Cited}

Braveman, N.S. and P. Bronstein. 1985. Experimental Assessments and Clinical Applications of Conditioned Food Aversion. Annals New York Acad. Sci. Vol 443.
Burritt, E.A. and F.D. Provenza. 1989. Food aversion learning: conditioning lambs to avoid a palatable shrub (Cercocarpus montanus). J. Anim. Sci. 67:650-653.

Burritt, E.A, and F.D. Provenza. 1996. Amount of experience and prior illness affect the acquisition and persistence of conditioned food aversions in lambs. Applied Anim. Behav. Sci. 48:73-80.

Galef, B.G., Jr. 1985. Socially induced diet preference can partially reverse a $\mathrm{LiCl}$-induced diet aversion. Anim. Learning Behav. 13:415-418.

Galef, B.G., Jr. 1986. Social interaction modifies learned aversions, sodium appetite, and both palatability and handling-time induced dietary preference in rats. J. Comparative Psychology 100:432-439.

Garcia, J., P.A. Lasiter, F. Bermudez-Rattoni, and D.A. Deems. 1985. A general theory of aversion learning. pp. 8-21. In: N.S. Braveman and P. Bronstein (Eds.), Experimental Assessments and Clinical Applications of Conditioned Food Aversion. Annals New York Acad. Sci. Vol 443.

Gustavson, C.R. and J.D. Gustavson. 1985. Predation control using conditioned food aversion methodology: theory, practice, and implications. pp. 348-356. In: N.S. Braveman and P. Bronstein (Eds.), Experimental Assessments and Clinical Applications of Conditioned Food Aversion. Annals New York Acad. Sci. Vol. 443.

Kruz, E.M. and D.A. Levitski. 1982. Novelty of contextual cues in taste aversion learning. Anim. Learning Behav. 10:229-232.

Lane, M.A., M.H. Ralphs, J.D. Olsen, F.D. Provenza, and J.A. Pfister. 1990. Conditioned taste aversion: potential for reducing cattle loss to larkspur. J. Range Manage. 43:127-131.

Layeock, W.A. 1978. Coevolution of poisonous plants and large herbivores on rangelands. J. Range Manage. 31:335-342.

Nachman, M., J. Rauschenberger, and J.H. Ashe. 1977. Stimulus characteristics in food aversion learning. pp. 105-131. In: N.W. Milgram, L. Krames, and T.M. Alloway (Eds.), Food Aversion Learning. Plenum Press, New York, N.Y.

Olsen, J.D. and M.F. Ralphs. 1986. Feed aversion induced by intraruminal infusion with larkspur extract in cattle. Amer. J. Vet. Res. 47:1829-1833.

Provenza, F.D. and D.F. Balph. 1988. Development of dietary choice in livestock on rangelands and its implications for management. J. Anim. Sci. 66:2356-2368.

Ralphs, M.H. and C.D. Cheney. 1993. Influence of cattle age, lithium chloride dose level, and food type in the retention of food aversions. J. Anim. Sci. 71:373-379.

Ralphs, M.H. and J.D. Olsen. 1990. Adverse influence of social facilitation and learning context in training cattle to avoid eating larkspur. $\mathrm{J}$. Anim. Sci. 68:1944-1952.

Ralphs, M.H. and J.D. Olsen. 1992. Comparison of larkspur alkaloid extract and lithium chloride in maintaining cattle aversion to larkspur in the field. J. Anim. Sci. 70:1116-1120.

Ralphs, M.H., D. Graham, M.L. Galyean, and L.F. James. 1997. Creating aversions to locoweed in naive and familiar cattle. J. Range Manage. 50:361-366.

Rozin, P. and D. Zellner. 1985. The role of Pavlovian conditioning in acquisitions of food likes and dislikes. pp. 189-202. In: N.S. Braveman and P. Bronstein (Eds), Experimental Assessments and Clinical Applications of Conditioned Food Aversion. Annals New York Acad. Sci. Vol 443.

SAS. 1988. SAS/STAT Users Guide (Release 6.0). SAS Inst. Inc, Cary, N.C.

Thorhallsdottir, A.G., F.D. Provenza, and D.F. Balph. 1990. Social influences on conditioned food aversions in sheep. Applied Anim. Behav. Sci. 25:45-50.

Zahorik, D.M. and K.A. Houpt. 1977. The concept of nutritional wisdom: applicability of laboratory learning models to large herbivores. pp. 45-67. In: L.M. Barker, M.R. Best, and M. Domjan (Eds.), Learning Mechanisms in Food Selection. Baylor Univ. Press, Waco, Tex.

Zahorik, D.M. and K.A. Houpt. 1990. Taste aversion learning in three species of ruminants. Applied Anim. Behav. Sci. 26:27-39. 